\title{
Zakres i struktura budżetu ogólnego UE
}

\author{
The Scope and Structure \\ of the General EU Budget
}

Streszczenie. Celem artykułu jest przedstawienie zakresu i struktury budżetu ogólnego Unii Europejskiej. Budżet ogólny UE jest konstruowany zgodnie z zasadami budżetowymi, które wymienione są w rozporządzeniu nr 966/2012. Zakres budżetu związany jest z podmiotami, których dochody i wydatki są ujmowane w budżecie. Wiąże się on z zasadą jedności i rzetelności budżetowej. Struktura i zawartość budżetu związane są natomiast z danymi wykazywanymi w budżecie i sposobem ich przedstawienia. Szczególne znaczenie w kontekście struktury i zawartości budżetu mają takie zasady, jak: uniwersalność, równowaga, specyfikacja.

Słowa kluczowe: budżet ogólny UE; zakres budżetu; struktura budżetu.

Abstract. The purpose of this article is to present the scope and structure of the general budget of the European Union. EU general budget is constructed in accordance with the budgetary principles that are set out in Regulation No $966 / 2012$. The scope of the budget is related to entities whose income and expenses are accounted for in the budget. It is connected with the principle of unity 
and budget accuracy. The structure and content of the budget, however, are associated with the data exhibited in the budget and the way they are presented. Of particular importance in the context of the structure and content of the budget are principles such as universality, balance, specification.

Keywords: EU general budget; the scope of the budget; the structure of the budget.

\section{Uwagi ogólne}

Budżet ogólny UE, jako budżet organizacji międzynarodowej, wykazuje pewne cechy szczególne odróżniające go od budżetów krajowych. Wskazać można na specyficzny charakter dochodów i wydatków tego budżetu, brak wyraźnie określonej formy prawnej ${ }^{1}$ czy oryginalną, złożoną procedurę jego przyjmowania.

Z drugiej jednak strony budżet ogólny wykazuje pewne podobieństwa do budżetów krajowych pod względem jego struktury i organizacji. Przede wszystkim należy zwrócić uwagę na to, że podobnie jak budżety krajowe jest konstruowany zgodnie z zasadami budżetowymi, które w wielu przypadkach mają wyraźne podstawy normatywne w Traktacie o funkcjonowaniu Unii Europejskiej lub w rozporządzeniach regulujących sprawy finansowe $\mathrm{UE}^{2}$.

Celem opracowania jest próba odpowiedzi na pytanie o zakres i strukturę budżetu ogólnego UE. W szczególności opracowanie ma na celu wskazanie, jakiego rodzaju dane i informacje są w nim wykazywane.

1 Na brak sprecyzowanej formy prawnej „dokumentu budżetowego” jako elementu odróżniającego budżet ogólny UE od budżetów krajowych zwraca uwagę C. Kosikowski, Prawo finansowe w Unii Europejskiej, Bydgoszcz-Warszawa 2008, s. 112. Budżet jest publikowany w Dzienniku Urzędowym UE serii L, zatytułowanym „Budżety”, co wskazuje na szczególny rodzaj aktu o charakterze legislacyjnym.

2 Na temat roli zasad budżetowych w budżecie ogólnym UE zob. M. Tyniewicki, Znaczenie klasycznych zasad budżetowych w budżecie ogólnym Unii Europejskiej, [w:] L. Etel, M. Tyniewicki (red.), Finanse publiczne i prawo finansowe - realia i perspektywy zmian. Księga Jubileuszowa dedykowana profesorowi Eugeniuszowi Ruśkowskiemu, Białystok 2012, s. 209 i n. Szczególne znaczenie w kontekście zakresu i struktury budżetu mają takie zasady, jak: jedność i rzetelność budżetowa (zupełność), uniwersalność (niefunduszowanie), równowaga, specyfikacja (szczegółowość). 
Prawne podstawy regulujące te kwestie zawarte są w Traktacie o funkcjonowaniu Unii Europejskiej ${ }^{3}$, a także w rozporządzeniach:

- rozporządzeniu Parlamentu Europejskiego i Rady (UE, Euratom) nr 966/2012 w sprawie zasad finansowych mających zastosowanie do budżetu ogólnego Unii oraz uchylającym rozporządzenie Rady (WE, Euratom) nr 1605/2002 4 ,

- $\quad$ rozporządzeniu delegowanym Komisji (UE) nr 1268/2012 w sprawie zasad stosowania rozporządzenia Parlamentu Europejskiego i Rady (UE, Euratom) nr 966/2012 w sprawie zasad finansowych mających zastosowanie do budżetu ogólnego Unii ${ }^{5}$.

\section{Zakres budżetu ogólnego}

Zgodnie z zasadami jedności i rzetelności budżetowej oraz zupełności budżet ogólny powinien swoim zakresem obejmować wszystkie dochody i wydatki UE oraz Europejskiej Wspólnoty Energii Atomowej ${ }^{6}$. Wskazuje się na wysoki stopień realizacji tej zasady - w budżecie ogólnym wykazuje się ponad 95\% wszystkich dochodów i wydatków UE7

Zgodnie z rozporządzeniem nr 966 w budżecie ogólnym wykazuje się dochody i wydatki UE łącznie z wydatkami administracyjnymi instytucji przewidzianymi w postanowieniach Traktatu o Unii Europejskiej, odnoszącymi się do wspólnej polityki zagranicznej i bezpieczeństwa, a także łącznie z wydatkami operacyjnymi poniesionymi przy wykonywaniu tych postanowień, jeżeli są one pokrywane z budżetu.

Dochody i wydatki UE obejmują dochody i wydatki instytucji UE, którymi dla potrzeb rozporządzenia nr 966 są: Parlament Europejski, Rada

Dz.Urz. UE C 326 z dnia 26 października 2012 r., s. 47 (wersja skonsolidowana).

Dz.Urz. UE L 298 z dnia 26 października 2012 r., s. 1 (dalej: rozporządzenie nr 966, rozporządzenie finansowe).

5 Dz.Urz. UE L 362 z dnia 31 grudnia 2012 r., s. 1 (dalej: rozporządzenie nr 1268, rozporządzenie delegowane).

6 Obie Wspólnoty, UE i EWEA, posiadają wspólny budżet. Dochody i wydatki EWEA są włączone do budżetu ogólnego i wykazywane we właściwych podziałkach klasyfikacyjnych. W dalszej części opracowania nazwa UE będzie używana dla określenia obu tych Wspólnot, chyba że w treści niezbędne będzie ich rozróżnienie.

7 M. Tyniewicki, Znaczenie klasycznych zasad..., s. 213. 
Europejska, Rada UE, Komisja Europejska, Trybunał Sprawiedliwości UE, Trybunał Obrachunkowy, Europejski Komitet Ekonomiczno-Społeczny, Komitet Regionów, Europejski Rzecznik Praw Obywatelskich, Europejski Inspektor Ochrony Danych oraz Europejska Służba Działań Zewnętrznych.

W budżecie UE ujmuje się także dochody i wydatki niektórych unijnych jednostek organizacyjnych, pozostających w strukturach administracyjnych instytucji UE, zwłaszcza Komisji. Jednostkami tymi są urzędy europejskie. Do urzędów europejskich zalicza się: Urząd Publikacji, Europejski Urząd ds. Zwalczania Nadużyć Finansowych, Europejski Urząd Doboru Kadr i Europejską Szkołę Administracji, Urząd Administracji i Wypłacania Należności Indywidualnych, Urzędy Infrastruktury i Logistyki w Brukseli i Luksemburgu (art. 195 rozp. nr 966 w zw. z art. 278 rozp. $\mathrm{nr}$ 1268).

W budżecie ogólnym nie wykazuje się dochodów i wydatków jednostek organizacyjnych UE posiadających odrębną osobowość prawną takich, jak: agencje wykonawcze, agencje zdecentralizowane, wspólne przedsiębiorstwa i inne tego rodzaju podmioty. Podmioty te posiadają swoje własne budżety operacyjne, które są publikowane w Dzienniku Urzędowym UE serii C. Podmioty te są finansowane głównie z budżetu ogólnego, w którym wykazuje się wydatki na ich rzecz (w sekcji Komisji w tytułach i rozdziałach właściwych dla przedmiotu ich działalności) czy dokonywane przez nie zwroty z tytułu osiąganych nadwyżek.

W budżecie ogólnym nie wykazuje się operacji pożyczkowych $\mathrm{UE}^{8}$. Działalność pożyczkowa UE polega na pozyskiwaniu środków na rynkach finansowych oraz udostępnianiu ich w formie pożyczek udzielanych przez UE na działania podejmowane w krajach członkowskich i krajach trzecich. Ze względu na wysoką wiarygodność może ona pozyskiwać środki na korzystniejszych warunkach niż państwa, którym udziela pożyczek.

8 L. Oręziak, Finanse Unii Europejskiej, Warszawa 2009, s. 230. Działalność pożyczkową może prowadzić zarówno UE, jak i EWEA, w przypadku której Traktat Euratom przewiduje wyraźną podstawę prawną dla zaciągania zobowiązań (art. 172 Traktatu ustanawiającego Europejską Wspólnotę Energii Atomowej, wersja skonsolidowana, Dz.Urz. UE C 327 z dnia 26 października 2012 r., s. 1). 
Operacje zaciągania i udzielania pożyczek realizowane są równolegle i są neutralne dla budżetu, o ile nie zajdzie potrzeba uruchomienia gwarancji budżetu dla tych operacji ${ }^{9}$. Działalność pożyczkowa UE ma inny cel niż działalność pożyczkowa państw członkowskich. O ile państwa, np. Polska, zaciągają pożyczki głównie na pokrycie deficytu budżetowego, to UE traktuje działalność pożyczkową jako instrument realizacji swoich celów (funkcję równoważenia budżetu ogólnego realizują bowiem wpłaty państw członkowskich oparte na ich dochodzie narodowym brutto). Nie zmienia to jednak faktu posiadania przez UE zobowiązań finansowych z tytułu tej działalności.

W budżecie ogólnym zapisuje się gwarancje związane z działalnością pożyczkową UE. Wykazuje się potencjalne wydatki z budżetu ogólnego w przypadku, gdy beneficjent pożyczki zaprzestałby jej spłacania, co doprowadziłoby do uruchomienia gwarancji budżetowych, a także wykazuje się dochody pochodzące z kwot odzyskanych od pożyczkobiorców opisanej powyżej sytuacji, gdy została już uruchomiona gwarancja. W celu zabezpieczenia budżetu ogólnego przed każdorazowym uruchamianiem gwarancji w sytuacji niewywiązywania się odbiorcy pożyczki z obowiązku spłaty utworzony został Fundusz Gwarancyjny dla działań zewnętrznych $^{10}$. Fundusz ten jest zasilany z budżetu ogólnego do określonej kwoty, zwanej kwotą docelową ${ }^{11}$, co jest wykazywane jako wydatki budżetu. W przypadku, gdy stan środków Funduszu przewyższa kwotę docelową, nadwyżka jest zwracana do budżetu. W budżecie ogólnym obok gwarancji oraz wydatków na zasilanie Funduszu Gwarancyjnego zamieszcza się także orientacyjne dane dotyczące bieżących operacji kapitałowych i ob-

9 L. Oręziak, Finanse Unii Europejskiej..., s. 230.

10 Rozporządzenie Rady (WE, Euratom) nr 480/2009 z dnia 25 maja 2009 r. ustanawiające Fundusz Gwarancyjny dla działań zewnętrznych, Dz.Urz. UE L 145 z dnia 10 czerwca 2009 r., s. 10 (dalej: rozporządzenie $\mathrm{nr} 480$ ).

11 Kwota docelowa wynosi 9\% łącznych wymagalnych zobowiązań kapitałowych Wspólnot, wynikających z każdej operacji, powiększonych o niespłacone należne odsetki (art. 3 rozp. nr 480). 
sługi zadłużenia oraz operacje kapitałowe i obsługę zadłużenia na rok budżetowy (rok $n)^{12}$.

W budżecie ogólnym nie ujmuje się finansów:

- banków: Europejskiego Banki Centralnego, Europejskiego Banku Inwestycyjnego wraz z Europejskim Funduszem Inwestycyjnym; nieujmowanie w budżecie finansów banków jest związane z charakterem tych podmiotów i ich działalności ${ }^{13}$ (w budżecie ogólnym ujmuje się jednak gwarancje z tytułu pożyczek udzielanych przez EBI , a także dywidendę z działalności EFI);

- Europejskiego Funduszu Rozwoju, którego celem jest wspieranie rozwijających się państw położonych w regionie Afryki, Karaibów i Pacyfiku oraz krajów i terytoriów zamorskich, zależnych od niektórych krajów członkowskich $\mathrm{UE}^{14}$;

- wydatków operacyjnych przypadających na operacje mające wpływ na kwestie wojskowe i polityczno-obronne oraz w innych przypadkach, gdy Rada jednomyślnie tak postanowi (art. 41 ust. 2 i 3 Traktatu o UE) ${ }^{15}$;

- dochodów uzyskanych z grzywien i kar pieniężnych, o ile decyzja o ich nałożeniu może być uchylona przez Trybunał Sprawiedliwości UE ${ }^{16}$.

12 Według stanu na rok 2013 roczna kwota, jaka musiałaby zostać zapłacona przez UE w 2013 r. przy założeniu niespłacenia wszystkich pożyczek przez ich odbiorców i przy założeniu, że niespłacenie to nie spowodowałoby przyspieszenia wymagalności całej kwoty gwarantowanych pożyczek, wyniosłaby 1.871,0 mln euro. W tym samym roku Fundusz Gwarancyjny byłby w stanie pokryć $49 \%$ ryzyka związanego z pożyczkami na rzecz krajów trzecich w tym roku (2.127,7 mln euro). Natomiast całkowita kwota zobowiązań UE z tytułu udzielonych pożyczek uwzględnianych w budżecie ogólnym wynosiła w 2013 r. 82.277,0 mln euro (z tytułu niespłaconego kapitału oraz odsetek). $72 \%$ z tej kwoty przypadło na państwa członkowskie (54\% ogółu kwoty pochłonął europejski mechanizm stabilizacji finansowej). Sprawozdanie Komisji dla Parlamentu Europejskiego i Rady w sprawie gwarancji pokrytych z budżetu ogólnego. Stan na dzień 31 grudnia 2012 r., COM (2013) 871 final, s. 9 i n.

M. Tyniewicki, Znaczenie klasycznych zasad..., s. 212.

14 Komisja od dawna postuluje jednak włączenie tego Funduszu do budżetu ogólnego.

L. Oręziak, Finanse Unii Europejskiej, s. 223-227.

15 M. Tyniewicki, Znaczenie klasycznych zasad..., s. 212.

16 Tamże, s. 212. 
Zgodnie z TfUE oraz rozporządzeniem nr 966 budżet ogólny realizuje zasadę równowagi budżetowej ${ }^{17}$. Zasada ta, znajdująca w przypadku budżetu ogólnego UE wyraźne podstawy prawne, powinna być bezwzględnie przestrzegana na etapie jego planowania i wykonywania. W rzeczywistości należy jednak zauważyć, że w praktyce budżet ogólny może wykazywać deficyt lub nadwyżkę. Mogą one wynikać z innego niż zakładany przebiegu wykonania budżetu ${ }^{18}$. Saldo danego roku budżetowego zapisuje się w budżecie na kolejny rok budżetowy jako dochody w przypadku nadwyżki lub jako środki na płatności w przypadku deficytu (art. 18 ust. 1 rozp. nr 966).

\section{Struktura budżetu ogólnego}

W literaturze wyróżnia się strukturę poziomą i pionową budżetu ogólnego ${ }^{19}$. Struktura pozioma związana jest z wykazywaniem dochodów i wydatków poszczególnych instytucji ujmowanych w budżecie. Wyrazem struktury poziomej jest podział budżetu na:

- ogólne zestawienie dochodów i wydatków,

- $\quad$ oddzielne sekcje dla każdej instytucji UE w rozumieniu rozporządzenia nr 966, zawierające zestawienia dochodów i wydatków (Rada Europejska i Rada UE są ujęte w jednej sekcji).

Struktura pionowa stanowi właściwą klasyfikację budżetową ${ }^{20}$. Jest ona związana z istnieniem ogólnych i szczegółowych jednostek (podziałek) klasyfikacyjnych, zwanych w prawie budżetowym UE liniami budżetowymi ${ }^{21}$. Podziałkami o charakterze ogólnym są tytuły i rozdziały.

\footnotetext{
17 „Unia oraz organy ustanowione na podstawie TfUE oraz Traktatu Euratom nie mogą zaciągać pożyczek w ramach budżetu” (art. 17 rozporządzenia nr 966). Zgodnie z tym artykułem wymóg zrównoważenia odnosi się do dochodów i środków na płatności. M. Tyniewicki, Znaczenie klasycznych zasad, s. 217.

19 M. Cieślukowski, Budżet Unii Europejskiej, Poznań 2006, s. 24 i n.; Ewolucję struktury budżetu ogólnego Wspólnot Europejskich przedstawia A. Komar, Gospodarka budżetowa Europejskich Wspólnot, Warszawa-Poznań 1981, s. 14 i n.

20 M. Cieślukowski, Budżet Unii Europejskiej..., s. 25.

21 M. Tyniewicki, Znaczenie klasycznych zasad..., s. 218.
} 
W ramach rozdziałów istnieją szczegółowe podziałki klasyfikacyjne artykuły i pozycje.

Dla instytucji innych niż KE dochody i wydatki klasyfikowane są zgodnie z ich rodzajem lub przeznaczeniem $\mathrm{w}$ ramach tytułów, rozdziałów, artykułów i pozycji.

W przypadku KE powyższa klasyfikacja dotyczy dochodów, natomiast wydatki w sekcji KE są klasyfikowane według celu, zgodnie z nomenklaturą ustanowioną przez PE i Radę (art. 44 rozporządzenia nr $966 / 2012)^{22}$. Tytuły odpowiadają obszarowi polityki, a rozdziały - co do zasady - odpowiadają danej działalności.

W ramach tytułów mogą być zawarte środki operacyjne oraz środki na wydatki administracyjne ${ }^{23}$. Te ostatnie są co do zasady grupowane $\mathrm{w}$ ramach tytułu $\mathrm{w}$ jednym rozdziale. $\mathrm{W}$ odrębnym tytule mogą być zawarte rezerwy (,środki tymczasowe”). Mogą być one tworzone w każdej sekcji. Środki w ramach tego tytułu mogą być wykorzystane po dokonaniu ich przesunięcia do właściwej podziałki klasyfikacyjnej (art. 46 rozporządzenia nr 966).

Sekcja Komisji może obejmować rezerwę ujemną, która wynosi maksymalnie 200.000.000 euro. Zawiera ona wyłącznie środki na płatności i jest zapisywana w oddzielnym tytule. Z art. 47 rozporządzenia nr 966 wynika, że utworzenie tej rezerwy nie jest obowiązkowe. Rezerwa ta musi być wykorzystana przed końcem roku budżetowego w drodze przesunięć środków. W szczególności może być ona wykorzystana dla zrównoważenia budżetu ${ }^{24}$.

Sekcja Komisji obejmuje rezerwę na pomoc nadzwyczajną dla państw trzecich. Rezerwa ta, jak wynika z rozporządzenia nr 966, jest obowiązkowa i powinna zostać wykorzystana przed końcem roku budżetowego w drodze przesunięć.

22 Klasyfikacja wydatków KE wg celu związana jest z reformą budżetową polegającą na przejściu na zarządzanie budżetem poprzez cele. L. Oręziak, Finanse Unii Europejskiej..., s. 154; M. Tyniewicki, Znaczenie klasycznych zasad..., s. 219.

23 Wydatki operacyjne to wydatki na realizację zadań przez Unię. Są one realizowane przez Komisję. Wydatki administracyjne związane są z bieżącą działalnością instytucji Unii. L Oręziak, Finanse Unii Europejskiej..., s. 154.

24 M. Tyniewicki, Znaczenie klasycznych zasad..., s. 217. 
Elementem budżetu ogólnego są również plany zatrudnienia personelu w poszczególnych instytucjach, a także jednostkach organizacyjnych (zarówno takich, których dochody i wydatki są ujęte w budżecie ogólnym, jak i tych posiadających własne budżety). Wykazy te przedstawiają liczbę stanowisk stałych i tymczasowych wraz z odpowiadającymi im grupami funkcyjnymi i stopniami zaszeregowania dla bieżącego roku budżetowego i roku ubiegłego. Znajdują się one w każdej sekcji budżetu. Plany zatrudnienia zawierają dane o charakterze niefinansowym (obok planów zatrudnienia w budżecie wykazuje się także wydatki na utrzymanie personelu poszczególnych instytucji i jednostek organizacyjnych).

Do budżetu ogólnego dołączane są załączniki, w których ujmuje się:

- działania Unii, w których uczestniczą państwa EFTA (są to wydatki finansowane ze składek państw EFTA stanowiących dochody przeznaczone na określony cel - art. 9 rozp. nr 1268);

- orientacyjne dane nt. bieżących operacji finansowych i obsługi zadłużenia (art. 49 ust. 1 lit. d (iii) rozp. nr 966);

- informacje nt. instrumentów finansowych (art. 49 ust. 1 lit. e rozp. nr 966);

- dochody i wydatki każdego urzędu europejskiego (art. 196 rozp. nr 966);

- $\quad$ wszelkie inne stosowne dokumenty (art. 49 ust. 2 rozp. nr 966).

\section{Zawartość budżetu}

Zawartość budżetu związana jest z rodzajem wykazywanych w budżecie ogólnym danych i mieści się w ramach struktury budżetu. Elementami tak rozumianej zawartości budżetu będą takie podziały środków budżetowych, jak podział na środki niezróżnicowane i zróżnicowane czy podział na środki na płatności i środki na zobowiązania.

Budżet zawiera środki zróżnicowane i środki niezróżnicowane. Na środki zróżnicowane składają się środki na zobowiązania i środki na płatności. Środki niezróżnicowane są to środki o charakterze bieżącym, takie jak wydatki administracyjne, zwroty od państw członkowskich, udzielone gwarancje w ramach pożyczek. Cechą środków niezróżnicowa- 
nych jest to, że ich planowanie i wydatkowanie następuje w tym samym roku budżetowym ${ }^{25}$.

Środki na zobowiązania pokrywają łączny poziom zobowiązań prawnych zaciągniętych w roku budżetowym. Oznaczają one limity, do których upoważnione podmioty wykonujące budżet ogólny mogą w danym roku zaciągać zobowiązania. Środki na płatności pokrywają płatności z tytułu zobowiązań prawnych zaciągniętych w roku budżetowym lub w poprzednich latach budżetowych (art. 10 rozporządzenia nr 966). Podział środków na środki na płatności i na zobowiązania związany jest ze sposobem prezentacji budżetu ogólnego zarówno w ujęciu kasowym (środki na płatności), jak i memoriałowym (środki na zobowiązania).

Maksymalne pułapy środków na płatności i środków na zobowiązania w danym roku budżetowym określają wieloletnie ramy finansowe. Ramy są przyjmowane przez Radę UE w drodze rozporządzenia, zgodnie ze specjalną procedurą, na co najmniej 5 lat. Zgodnie z TfUE, roczny budżet musi być zgodny z wieloletnimi ramami finansowymi. Rozwiązanie to, wynikające ze specyfiki UE jako organizacji międzynarodowej, zapewnia silną pozycję wieloletnich ram finansowych jako instrumentu planowania średnioterminowego.

Zarówno w ogólnym zestawieniu dochodów i wydatków, jak i w sekcjach, stosuje się następujący sposób prezentacji dochodów i wydatków:

- $\quad$ szacowane dochody UE na dany rok budżetowy (rok $n$ );

- $\quad$ szacowane dochody za poprzedni rok budżetowy oraz dochody za rok $n-2$;

- $\quad$ środki na zobowiązania i środki na płatności na rok $n$;

- środki na zobowiązania i środki na płatności za poprzedni rok budżetowy;

- $\quad$ zobowiązania zaciągnięte i wydatki zrealizowane w roku $n-2$, przy czym wydatki wyraża się również jako procent budżetu z roku $n$;

- uwagi na temat poszczególnych części nomenklatury budżetowej; uwagi zawierają odniesienia do aktów podstawowych, stanowiących podstawę ujmowania dochodów i środków w budżecie ogólnym,

25 Tamże, s. 215. 
a także wszystkie właściwe wyjaśnienia dotyczące charakteru i celu środków.

W niektórych przypadkach w budżecie ogólnym stosowany jest zapis symboliczny pro memoria, który w świetle rozporządzeń nr 966 (np. art. 21) oraz 1268 (np. art. 7, 9, 10) dotyczy m.in.:

- dochodów przeznaczonych na określony cel ${ }^{26}$ (art. 21 rozp. nr 966 w zw. z art. 7 rozp. nr 1268);

- dochodów z tytułu potencjalnych odsetek od kwot z tytułu sankcji nakładanych w ramach procedury nadmiernego deficytu (art. 10 rozp. nr 1268);

- potencjalnych zwrotów od pożyczkobiorców w sytuacji, gdy korzystali z pożyczek gwarantowanych przez budżet ogólny i niespłacenie przez nich zobowiązania spowodowało uruchomienie gwarancji.

Treść rozporządzeń nr 966 i 1268 wskazuje, że zapis pro memoria stosuje się w sytuacji, gdy nie jest możliwe podanie konkretnej kwoty.

\section{Budżet ogólny na 2014 r.}

Budżet ogólny na 2014 rok $^{27}$ liczy łącznie 1990 stron. Budżet składa się z ogólnego zestawienia dochodów i wydatków oraz z dziesięciu sekcji: I Parlament, II - Rada Europejska i Rada, III - Komisja, IV - Trybunał Sprawiedliwości Unii Europejskiej, V - Trybunał Obrachunkowy, VI Europejski Komitet Ekonomiczno-Społeczny, VII - Komitet Regionów, VIII - Europejski Rzecznik Praw Obywatelskich, IX - Europejski Inspektor Ochrony Danych, X - Europejska Służba Działań Zewnętrznych.

Dokument budżetowy liczy dwa tomy: pierwszy z nich zawiera ogólne zestawienie dochodów (s. 9-124) oraz dochody i wydatki instytucji innych niż Komisja (s. 125-551), a drugi dochody i wydatki samej Komisji (s. 1-1430).

26 Budżet ogólny realizuje zasadę uniwersalności, od której wyjątkiem są dochody przeznaczone na określony cel (art. 21 rozp. nr 966). Znajdują one odzwierciedlenie w strukturze budżetu (por. art. $7 \mathrm{i}$ n. rozp. nr 1268).

27 Dz.Urz. UE L 51 z dnia 20 lutego 2014 r., s. 1. 
Klasyfikacja (nomenklatura) budżetowa ustalona jest w samym akcie budżetowym (zgodnie z art. 44 rozp. nr 966, jest ona ustalana przez Parlament i Radę). W budżecie na 2014 r. dla dochodów, w ogólnym zestawieniu dochodów przewidziano ich podział na tytuły: 1 - Zasoby własne, 3 - Nadwyżki, salda i dostosowania, 4 - Dochody pochodzące od osób pracujących w instytucjach i innych organach Unii, 5 - Dochody z działalności administracyjnej instytucji, 6 - Wkłady i zwroty związane z realizacją porozumień i programów unijnych, 7 - Odsetki od zaległych płatności i grzywny, 8 - Operacje zaciągania i udzielania pożyczek, 9 - Dochody różne.

W ramach tytułów występują rozdziały, np. w tytule 4 są rozdziały 4.0 - różne podatki i potrącenia, 4.1 - składki na ubezpieczenia emerytalne i rentowe, 4.2 - inne składki na ubezpieczenia emerytalne i rentowe.

Na początku każdej sekcji znajdują się planowane dochody zawierające środki własne danej instytucji. Środki własne pochodzą z takich tytułów, jak tytuły 4-7 i 9. W planowanych dochodach ujmuje się przewidywany wkład finansowy UE na rzecz danej instytucji, wynikający z różnicy pomiędzy poziomem środków własnych a wydatkami instytucji. W zestawieniach dochodów instytucji wykazywane są jedynie ich dochody własne ${ }^{28}$. Natomiast dochody z tytułów takich, jak 1 i 3 są wykazywane w ogólnym zestawieniu dochodów.

W każdej sekcji znajduje się zestawienie dochodów i wydatków. Ujmuje się dochody na rok 2014, dochody w roku 2013 oraz jako \% 2012/2014. Są one podzielone na tytuły, rozdziały, artykuły i pozycje, zgodnie z klasyfikacją budżetową. Dla każdego tytułu wykazywane są także uwagi odnoszące się do poszczególnych artykułów i pozycji dochodów.

Wykaz wydatków w każdej sekcji obejmuje ogólne zestawienie środków w latach 2014 i 2013 oraz wynik roku 2012. Ogólne zestawienie określa wydatki według tytułów i rozdziałów. Np. w sekcji I - Parlament przewidziano takie tytuły wydatków, jak: Tytuł 1 - Osoby pracujące dla instytucji, Tytuł 2 - Budynki, meble, wyposażenie, i różne wydatki operacyjne, Tytuł 3 - Wydatki związane $\mathrm{z}$ wykonywaniem przez instytucję

28 W sekcji Komisji zawarto plan dochodów obejmujący tytuły 4-9. Nie zawarto informacji o wkładzie UE. 
zadań zwyczajowych, Tytuł 4 - Wydatki związane z wykonywaniem przez instytucję szczególnych zadań, Tytuł 10 - Inne wydatki, zawierający środki rezerwowe. Podobne tytuły wydatków występują we wszystkich sekcjach z wyjątkiem Komisji, w której tytuły wydatków odpowiadają obszarom polityki prowadzonej przez Komisję.

Najbardziej interesującymi elementami budżetu wydają się być ogólne zestawienie dochodów oraz sekcja III - Komisja. O ile sekcje pozostałych instytucji zawierają wyłącznie wydatki administracyjne, w sekcji Komisji oprócz wydatków administracyjnych zawarte są wydatki operacyjne związane z realizacją wszystkich polityk Unii Europejskiej ${ }^{29}$. Wywiera to wpływ na znaczną objętość tomu II - budżetu. W literaturze wskazuje się, że wydatki operacyjne stanowią ok. 95\% wszystkich wydatków budżetu ogólnego ${ }^{30}$. Podobnie kształtują się również wydatki operacyjne w budżecie ogólnym na 2014 r. Obok tytułów przyporządkowanych obszarom polityki i zawierającym wydatki operacyjne oraz (w osobnym rozdziale) wydatki administracyjne w sekcji Komisji występuje tytuł XX zawierający wydatki administracyjne przypisane obszarom polityki. W osobnym tytule (40) ujęto rezerwy. W sekcji Komisji i w załącznikach do niej zawarte są wszelkie istotne dane związane z realizacją zadań Unii Europejskiej, w tym dotyczące realizowanych przez UE polityk i programów, gwarancji udzielanych z budżetu ogólnego, dochodów i wydatków urzędów europejskich, wydatków związanych z realizacją programów unijnych przez organy zdecentralizowane, informacje o działalności pożyczkowej UE i inne.

We wszystkich sekcjach zachowana jest przejrzysta struktura prezentowanych danych, obejmująca zestawienia dochodów i wydatków ze szczegółowością do artykułu i pozycji wraz z zamieszczanymi pod nimi uwagami.

Na końcu każdej sekcji znajduje się wykaz dotyczący personelu, w którym przedstawia się liczbę stanowisk stałych i tymczasowych wraz

29 W budżecie na 2014 r. w sekcji Komisji ujęto 34 tytuły poświęcone poszczególnym obszarom działalności UE.

30 M. Cieślukowski, Budżet Unii Europejskiej..., s. 25; M. Tyniewicki, Znaczenie klasycznych zasad..., s. 219. 
z odpowiadającymi im grupami funkcyjnymi i stopniami zaszeregowania dla roku 2013 i 2014. W sekcji Komisji ujęto personel samej Komisji, urzędów europejskich i organów zdecentralizowanych.

\section{Podsumowanie}

Budżet ogólny UE posiada precyzyjnie określony zakres, strukturę i zawartość, wyrażone w przepisach TfUE oraz rozporządzeń nr 966 i 1268. Rozporządzenia te zawierają przepisy ustalające szczegółową budowę „dokumentu budżetowego”. Regulacje te stanowią wyraz znaczenia, jakie UE przywiązuje do aktu budżetowego. Jak wspomniano wyżej, budżet ogólny realizuje klasyczne zasady budżetowe, które mają w UE charakter normatywny i do których przywiązuje się duże znaczenie.

Pod względem zakresu budżet ogólny, podobnie jak budżety krajowe, realizuje zasadę zupełności, zwaną w prawie finansowym UE zasadą jedności i rzetelności budżetowej. Realizuje również zasadę specyfikacji, posiadając konkretną strukturę budżetową zawierającą ogólne i szczegółowe podziałki klasyfikacyjne.

Regulacje unijne dotyczące struktury i zawartości budżetu ogólnego UE zawierają pewne rozwiązania niewystępujące w polskich przepisach, związane ze sposobem prezentacji wielkości budżetowych (prezentacja budżetu w ujęciu kasowym i memoriałowym, środki pro memoria, prezentowanie wielkości za poprzednie lata budżetowe i in.).

Zwraca uwagę przejrzysta struktura dokumentu budżetowego, zawierającego szczegółowy wykaz przewidywanych dochodów i planowanych wydatków. Dzięki niej budżet ogólny realizuje także funkcję informacyjną, związaną z dostępnością wiedzy na temat gospodarki finansowej UE dla jej obywateli. Funkcję taką pełnią m.in. uwagi, które zamieszczane są przy artykułach i pozycjach dochodów i wydatków, a więc przy najbardziej szczegółowych podziałkach klasyfikacji budżetowej. Uwagi zawierają odniesienie do aktów stanowiących podstawę prawną ich pobierania lub dokonywania, a także inne informacje wyjaśniające pochodzenie lub przeznaczenie środków budżetowych. 


\section{Bibliografia:}

Cieślukowski M., Budżet Unii Europejskiej, Wydawnictwo Akademii Ekonomicznej w Poznaniu, Poznań 2006.

Komar A., Gospodarka budżetowa Europejskich Wspólnot, PWN, Warszawa-Poznań 1981.

Kosikowski C., Prawo finansowe w Unii Europejskiej, Oficyna Wydawnicza Branta, Bydgoszcz-Warszawa 2008.

Oręziak L., Finanse Unii Europejskiej, PWN, Warszawa 2009.

Tyniewicki M., Znaczenie klasycznych zasad budżetowych w budżecie ogólnym Unii Europejskiej, [w:] Etel L., Tyniewicki M. (red.), Finanse publiczne i prawo finansowe - realia i perspektywy zmian. Księga Jubileuszowa dedykowana profesorowi Eugeniuszowi Ruśkowskiemu, Wydawnictwo Temida 2, Białystok 2012. 